\title{
The effects of pre-op trainning on the anxiety levels of children in Corum/Turkey
}

\author{
Selen Ozakar Akca ${ }^{1 *}$, Duygu Gozen² ${ }^{2}$, Yeliz Yelen Akpinar ${ }^{3}$ \\ ${ }^{1}$ Dr. and Assistant professor at Hitit University Health School, Corum, Turkey \\ ${ }^{2}$ Dr. and Associate professor at Istanbul University Florence Nightingale Faculty of Nursing, Istambul, Turkey \\ ${ }^{3}$ Education Director of the Association of Public Hospitals, Corum, Turkey
}

Study conducted at the Hitit University, Health School, Corum, Turkey

Article received: $8 / 1 / 2014$ Accepted for publication: 8/9/2014

*Correspondence: Address: Hitit University, Health School, Samsun Cad., 96 Corum, Turkey Postal code: 1259 Phone: +903642230732 Fax: +9036422230730 selenozakar@hotmail.com, selenozakar@gmail.com, selenozakar@hitit.edu.tr

http://dx.doi.org/10.1590/1806-9282.61.02.121 Financial support: none Conflict of interest: none

\section{SUMmaRY}

Objective: all individuals regardless of their age or level of development require physical, emotional and cognitive preparation before an operation. It is known that the attitudes of pediatric nurses towards pediatric patients are influential on the anxiety levels of children awaiting an operation. This study aims to determine the effect of pre-op trainning on the anxiety levels of pediatric patients hospitalized for hernioplasty surgery.

Methods: this cross sectional and quasi-experimental study included a total of 100 patients aged 7-12 years admitted for inguinal hernia surgery, 50 of which were the control group and 50 the experiment group. The data was gathered using the patients' identification forms and a child steady state anxiety scale. Research data was evaluated with appropriate statistical methods.

Results: the groups showed similar socio-demographic features and no statistically significant difference was observed ( $p>0.05$ ). During the pre-op period neither of the groups showed any statistically significant difference in terms of both state and trait anxiety levels ( $p>0.05$ ), however the experiment group showed a statistically significant drop in their anxiety levels during the post-op period $(\mathrm{p}<0.05)$.

Conclusion: the state anxiety levels of children receiving a planned pre-op trainning are lower compared to children who did not receive such trainning. Reducing the anxiety levels of sick children is possible through giving visual and tangible information appropriate with the age and developmental level of the sick child during the pre-op period.

Keywords: child, pediatric, hernia surgery, anxiety, perioperative care.

\section{INTRODUCTION}

All individuals regardless of their age or level of development require physical, emotional and cognitive preparation before an operation. ${ }^{1,2}$ Providing pre-op trainning for sick children is among the important duties of nurses who are members of pediatric surgery teams, and such trainning is necessary for the physical, emotional and cognitive preparation of the patients. ${ }^{3,4}$ Most studies indicate that healthcare interferences attempted before admission and operation is influential on the child's anxiety and concerns. $5,6,7$

Children often experience fear, anger, guilt, anxiety and stress during the pre-op period. Age and cognitive development of the child, time to be spent in hospital, treatment method and nature of the illness affect the anxiety levels of sick children. ${ }^{4,6}$ It is reported that sick children receiving pre-op preparation and trainning experience less post-op anxiety and recover faster. ${ }^{4,5,7}$

\section{Methods}

This research, which is planned based on the idea that the anxiety levels of sick children admitted to hospitals where a pre-op trainning program exists decrease, aims to determine the effects of pre-op trainning on the anxiety levels of sick children admitted to the Pediatric Wards with inguinal hernia diagnosis.

This cross sectional and quasi-experimental study was performed at the State Hospital Pediatric Ward in Corum/ Turkey. The study population consisted of sick 7-12 year- 
old children who were admitted to the State Hospital for inguinal hernia surgery. The sample group included 7 to 12 year-old inpatients from the State Hospital with no auditory or visual loss, or psychiatric history, which were open for cooperation and who have willingly accepted to take part in the research through improbabilistic sampling method. 100 patients were approached during the data collection period; all the patients and their families willingly took part in the research and they were divided into two groups of $50 \mathrm{pa}-$ tients, as experiment and control groups. Before the beginning of the study, the ethics committee approval was obtained. Additionally, the parents of the volunteer children participating were informed regarding the purpose of the study and a written consent was also obtained from them.

The data was gathered using the patients' identification forms, and a child steady state anxiety scale was prepared by the researchers. The patients in the control group were provided with the already existing oral information regarding the surgery, while the patients in the experiment group received audio visual trainning, including pictures of the surgical procedure, as a brochure prepared by the authors. Before starting with the research, the parents of the volunteer adolescent participants were informed regarding the purpose of the study and a written consent was obtained from them.

The patient identification form consists of 10 identifying questions regarding age, gender, family type, number of siblings, physical environment, health insurance, family income, chronic diseases, other health issues and previous surgeries. This form was filled by the researcher during 10 minute face to face interviews with patients in both the experiment and the control groups.

State-trait anxiety scale for children was created by Spielberger, in 1976, with two sub-scales of 20 questions for state-trait anxiety. ${ }^{8}$ Each item receives 0,1 or 2 points according to the intensity of the symptom. Trait anxiety defines how the individual generally feels and reflects the individual's tendency to anxiety. State anxiety defines the anxiety felt by the individual at a certain time and under certain circumstances that may also show alterations according to external factors. The validity and reliability tests of the scale were performed by Ozusta. ${ }^{9}$ The score obtained from the test for both state and trait anxiety varies from 20 to 60 points, and higher scores are considered as higher anxiety levels. The scale was applied to both groups, following the patient identification form.

Following the patient identification form and the statetrait anxiety scale for children, the sick children in the experiment group received trainning accompanied by a picture brochure, while the patients in the control group received the standard oral hospital trainning. The anxiety scale for children was again applied post-op to both groups and the pre- and post-op anxiety levels were compared.

Percentage and chi-square tests were used to analyze the socio-demographic features for evaluating the research data. Significance test between differences of two averages was used to analyze the pre-op state and trait anxiety levels. Significance test between differences of two pairs and covariance tests were used to analyze post-op state and trait anxiety levels. The statistical significant was accepted as $\mathrm{p}<0.05$.

\section{Results}

The comparison of the identifying features of the patients in both the experiment and the control groups are given in Table 1 . The average age of the patients included in the research was $9.62 \pm 1.6$ years in the experiment group and $9.4 \pm 1.5$ years in the control group. $44 \%$ of the patients included in the research were female and 56\% were male.

The variation according to the family type of the children in this research indicates that the majority in both groups (60 and 66\%) belongs to a core family unit. The majority of children in both groups (68 and 70\%) had 2 or more siblings, $52 \%$ of the children in the experiment group and $54 \%$ of the children in the control group lived in a rural area, $20 \%$ of the children in the experiment group and $30 \%$ of the children in the control group had more expenses than income. The authors found that the majority of the children in both groups ( 88 and $76 \%$ ) had health insurance, very few of the children in both groups ( 6 and $16 \%$ ) had a chronic illness and only $12 \%$ of the children in both the experiment and control groups had additional health issues. Regarding previous surgeries underwent by the children, $12 \%$ in both the experiment and control groups had undergone previous surgeries and $88 \%$ of the children in both groups had no previous surgery experience. No statistically significant difference was observed when the comparison of the identifying features of the patients in both groups (experiment/control) such as average age, $(\mathrm{p}=0.264)$, gender $(\mathrm{p}=0.459)$, family type $(\mathrm{p}=0.187)$, number of siblings ( $\mathrm{p}=0.897)$, physical environment $(\mathrm{p}=0.412)$, family income $(\mathrm{p}=0.412)$, health insurance $(\mathrm{p}=0.557)$, chronic illnesses ( $p=0.538)$, other health issues $(p=0.715)$ or previous surgeries $(\mathrm{p}=0.571)$, and the children in both groups presented similar variation ( $p>0.05$, Table 1$)$.

When the pre-op state and trait anxiety levels of the children, in both the experiment and control groups, are compared using the significance test between differences of two averages, both the pre-op state and trait anxiety levels $(\mathrm{CAL}=47.2 \pm 7.4 ; \mathrm{SAL}=52.3 \pm 6.2)$ of the children in the experiment group were higher than that of the chil- 
TABLE 1 Comparison of the identifying features of the patients in both the experiment and the control group.

\begin{tabular}{|c|c|c|c|c|c|}
\hline \multirow[t]{2}{*}{ Identifying features of the children } & \multicolumn{2}{|c|}{ Experiment $(n=50)$} & \multicolumn{2}{|c|}{ Control $(n=50)$} & \multirow[t]{2}{*}{$\mathrm{p}$ value } \\
\hline & $\mathbf{N}$ & $(\%)$ & $\mathbf{N}$ & $(\%)$ & \\
\hline \multicolumn{6}{|l|}{ Gender } \\
\hline Female & 22 & 44.0 & 22 & 44.0 & \multirow{2}{*}{$\mathrm{p}=.459 * *$} \\
\hline Male & 28 & 56.0 & 28 & 56.0 & \\
\hline \multicolumn{6}{|l|}{ Family type } \\
\hline Core & 30 & 60.0 & 33 & 66.0 & \multirow{2}{*}{$\mathrm{p}=.187^{* *}$} \\
\hline Extended family & 20 & 40.0 & 17 & 34.0 & \\
\hline \multicolumn{6}{|l|}{ Number of siblings } \\
\hline $1 \geq$ & 16 & 32.0 & 15 & 30.0 & \multirow{2}{*}{$\mathrm{p}=.897^{* *}$} \\
\hline $2 \leq$ & 34 & 68.0 & 35 & 70.0 & \\
\hline \multicolumn{6}{|l|}{ Living area } \\
\hline Urban & 26 & 52.0 & 27 & 54.0 & \multirow{2}{*}{$\mathrm{p}=.412 * *$} \\
\hline Rural & 24 & 48.0 & 23 & 46.0 & \\
\hline \multicolumn{6}{|l|}{ Family income } \\
\hline More expenses than income & 10 & 20.0 & 15 & 30.0 & \multirow{3}{*}{$\mathrm{p}=.412^{* *}$} \\
\hline Income equal to expenses & 31 & 62.0 & 22 & 44.0 & \\
\hline More income than expenses & 9 & 18.0 & 13 & 26.0 & \\
\hline \multicolumn{6}{|l|}{ Health insurance } \\
\hline Yes & 44 & 88.0 & 38 & 76.0 & \multirow{2}{*}{$\mathrm{p}=.557^{* *}$} \\
\hline No & 6 & 12.0 & 12 & 24.0 & \\
\hline \multicolumn{6}{|l|}{ Chronic illnesses } \\
\hline Yes & 3 & 6.0 & 8 & 16.0 & \multirow{2}{*}{$\mathrm{p}=.538^{* *}$} \\
\hline No & 47 & 94.0 & 42 & 84.0 & \\
\hline \multicolumn{6}{|l|}{ Other health issues } \\
\hline Yes & 6 & 12.0 & 6 & 12.0 & \multirow{2}{*}{$\mathrm{p}=.715^{* *}$} \\
\hline No & 44 & 88.0 & 44 & 88.0 & \\
\hline \multicolumn{6}{|l|}{ Previous surgeries } \\
\hline Yes & 6 & 12.0 & 6 & 12.0 & \multirow{2}{*}{$\mathrm{p}=.571^{* *}$} \\
\hline No & 44 & 88.0 & 44 & 88.0 & \\
\hline Average age & 9.6 & & 9.4 & & $\mathrm{p}=.264 * *$ \\
\hline
\end{tabular}

Note: Values are given in $n$ and \%. p $<0.05^{*}, \mathrm{p}>0.05^{* *}$

dren in the control group $(\mathrm{CAL}=46.4 \pm 5.3 ; \mathrm{SAL}=50.3 \pm 5.1)$; however, the difference found was not statistically significant $(t=0.045, p=0.962$, Table 2$)$.

TABLE 2 Distribution of the pre-op state and trait anxiety levels of the children in both the experiment and control groups.

\begin{tabular}{llll} 
& Experiment $(\mathbf{n}=\mathbf{5 0})$ & Control $(\mathbf{n = 5 0})$ \\
\hline & $\mathbf{x} \pm \mathbf{S D}$ & $\mathbf{x} \pm \mathbf{S D}$ & $\mathbf{P}$ value \\
\hline $\begin{array}{l}\text { Trait anxiety } \\
\text { levels }\end{array}$ & $47.2 \pm 7.4$ & $46.4 \pm 5.3$ & $0.962^{*}$ \\
\hline $\begin{array}{l}\text { State anxiety } \\
\text { levels }\end{array}$ & $52.3 \pm 6.2$ & $50.3 \pm 5.1$ & $0.338^{*}$ \\
\hline $\begin{array}{l}\text { Notes. Values are given as arithmetic average }(x) \pm \text { standard deviation }(\mathrm{SD}) . \\
\text { * Significance test between differences of two averages. }\end{array}$ &
\end{tabular}

When the pre-op and post-op state and trait anxiety levels of the children in both the experiment and control groups are compared using the significance test between differences of two pairs, the difference found in the control group was not statistically significant $(t=0.998$, $\mathrm{p}=0.354)$; however, the difference in the experiment group $(t=18.292$, $p=0.000$; Table 3$)$ in the post-op period was considered highly statistically significant.

The post-op levels of anxiety were compared after a correction made accordingly with the covariance analysis. A statistically significant difference $(\mathrm{p}<0.01)$ regarding the post-op state anxiety levels of the two groups was found. It was determined that the pre-op trainning received by the experiment group had the pre-op state anxiety levels influence the patient's post-op anxiety levels ( $\mathrm{p}<0.01$; Table 3 ). 
TABLE 3 Distribution of the pre and post-op state and trait anxiety levels of the children in both the experiment and control groups.

\begin{tabular}{lcccc} 
& \multicolumn{2}{c}{ Experiment $(\mathbf{n}=\mathbf{5 0})$} & \multicolumn{2}{c}{ Control $(\mathbf{n}=\mathbf{5 0})$} \\
\hline & $\mathbf{x} \pm \mathbf{S D}$ & $\mathbf{P}$ value & $\mathbf{x} \pm \mathbf{S D}$ & $\mathbf{p}$ value \\
\hline $\begin{array}{l}\text { Pre-op state } \\
\text { anxiety levels }\end{array}$ & $52.3 \pm 6.2$ & 0.000 & $50.3 \pm 5.1$ & $0.354^{*}$ \\
\hline $\begin{array}{l}\text { Post-op state } \\
\text { anxiety levels }\end{array}$ & $36.4 \pm 6.5$ & 0.000 & $48.5 \pm 5.2$ & $0.354^{*}$ \\
\hline
\end{tabular}

Notes. Values are given arithmetic average $(x) \pm$ standard deviation (SD).

* Significance test between differences of two pairs.

\section{Discussion}

The findings of this study reveal that the state anxiety levels of children receiving planned pre-op trainning are lower compared to the control group.

The comparison of the identifying features of the patients in both the experiment and control groups showed no statistically significant difference ( $p>0.05$; Table 1 ). The preop anxiety levels of the patients in both groups were found to be statistically similar (Table 2 ). The similar pre-op features of the patients in both groups and the homogeneity of the groups was an important factor in determining the effectiveness of the trainning given by the researcher.

In their study, Sar1 et al. ${ }^{10}$ found no statistically significant difference between the anxiety levels of 70 female and male children aged 6-12. In their study, Baygin et al. ${ }^{11}$ did not find a statistically significant difference between the anxiety levels of male and female children aged 6-12, either. The findings of the research revealed that the patients in both the experiment and control groups had similar identifying pre-op features (Table 1) and the pre-op state-trait anxiety levels of both groups were also similar, corroborating finds in the literature..$^{10,11}$

In a study by Turan et al. ${ }^{12}$ on adolescents aged 10-13 years awaiting surgical operations, the results revealed that the patients had a state anxiety level of $37.38 \pm 8.00$, and the patients aged 14 older had a state anxiety level of $45.62 \pm 9.12$. In another study by Caumo et al. ${ }^{16}$ on children aged 7-13 years, the trait pre-op anxiety level of the children was $38.58 \pm 6.54$, while the state anxiety level was found at $32.12 \pm 7.95$.

In the study by William Li and $\mathrm{Lam}^{18}$ on children aged 7-12 years, the pre-op state anxiety level average score was reported at $38.77 \pm 7.52$. The state anxiety level of the experiment group was found at $52.3 \pm 6.2$ and $50.3 \pm 5.1$, in the control group. And according to other studies, ${ }^{12,16,18}$ state-trait anxiety levels were higher in the research group (Table 2). According to Watson and Visram's ${ }^{17}$ literature study, regarding pre-op anxiety and post-op behavior of children, the children aged 7-11 years had a higher anxi- ety level and they wanted to be included in the decision-making process of the operation. Thus, the necessary pre-op explanation regarding the operation must be given in a stress free environment. The research group, also being aged 7-11 years, is a corroborative finding considering the higher state-trait anxiety levels than Turan's ${ }^{12}$ research, which may be related to age. When comparing the age range ${ }^{16,18}$ with the literature, where the range is similar, the higher state and trait anxiety levels are thought to be resulting from differences in countries and cultures.

$\mathrm{Ng}$ et al. ${ }^{13}$ state that pre-op briefing is a civilized and ethical approach and is effective in reducing the anxiety level of patients. It is found that the state anxiety level averages of children receiving planned pre-op trainning using visual materials are significantly lower and statistically significant, compared to children receiving the standard oral trainning given at the hospital (Table 3). This result proves that children are more interested in visual materials, and the use of such materials for the trainning of sick children is far more effective to reduce anxiety levels.

In their study, Kain et al. ${ }^{14}$ found that trainning programs for operations, including cognitive approaches such as therapeutic games and an introduction to the operating room 5-7 days before the surgery, reduces the anxiety levels of patients older than 6 years. Ucak and $\mathrm{Kivrak}^{19}$ report that the use of a coloring book reduces the anxiety levels of the children and parents undergoing adenotonsillectomy operations. This study also revealed that the trainning given with the support of visual materials during the pre-op period reduced the anxiety levels of the sick children in the experiment group, compared to the child patients in the control group (Table 3).

As a result of the research, it is found that there is no significant difference regarding the pre-op period. The high state and trait anxiety levels during the pre-op period (Table 2) and the lower and statistically significant difference in the state and trait anxiety levels of the patients in the experiment group compared to the control group is a finding that proves the efficiency of the trainning given by the researcher (Table 3 ).

\section{Conclusion}

A statistically significant difference was found between the pre- and post-op state and trait anxiety levels of children. It is thought that the oral briefing given at the hospital does not include enough information, creating uncertainty and causing a negative influence on the anxiety levels of the children. The lack of adequate pre-op preparation increases the fear and anxiety in sick children. Reducing the anxiety levels of sick children is possible by using visual and tangible 
information appropriate to the age and developmental level of the sick child during the pre-op period.

The time to start pre-op preparation, when and how much information should be given is directly related to the child's age and developmental level. This period shall be adequate enough to allow the child to ask questions and not be so long that would create unnecessary anxiety. ${ }^{5,16}$ Due to the concerns of sick children aged 6-12 regarding their body image, they would like to know details regarding whether they will be awake during the operation, how long the procedure will take, when they will be able to walk, and how they will look after the operation. The answers must be given honestly; the steps of the procedure should be explained using a model or audio visual material (posters, videos, brochures) on a step by step basis in order to reduce the anxiety levels. ${ }^{15,16,18}$

\section{ACKNOWLEDGMENTS}

This study was presented as a poster at the $49^{\text {th }}$ Turkish Congress of Paediatrics \& International Association for Adolescent Health $-10^{\text {th }}$ World Congress $\& 1^{\text {st }}$ Congress of Paediatric Association of the Balkan, Istanbul, 10-13 Haziran 2013.

\section{Resumo}

Os efeitos do preparo pré-operatório nos níveis de ansiedade de crianças em Corum/Turquia.

Objetivo: todo indivíduo, independentemente da idade ou fase de desenvolvimento, requer preparo físico, emocional e cognitivo antes de qualquer operação. Sabe-se que a atitude dos enfermeiros frente ao paciente pediátrico tem influência sobre o nível de ansiedade das crianças que esperam para serem operadas. Este estudo tem como objetivo determinar o efeito do preparo pré-operatório sobre os níveis de ansiedade de pacientes pediátricos hospitalizados para procedimento de hernioplastia. Métodos: este estudo transversal e quase-experimental incluiu um total de 100 pacientes com idade de 7 a 12 anos internados para cirurgia de hérnia inguinal; 50 deles formaram o grupo de controle e os demais 50 , o grupo de experimento. Os dados foram colhidos a partir de formulários de identificação dos pacientes e uma escala de estado-traço de ansiedade para crianças. Os dados da pesquisa foram avaliados com os devidos métodos estatísticos. Resultados: os grupos mostraram características sociodemográficas semelhantes e nenhuma diferença estatisticamente significativa foi observada ( $p>0,05)$. Durante o período pré-operatório, nenhum dos grupos apresentou qualquer diferença estatisticamente significativa em termos de níveis de estado de ansiedade ou traços ( $\mathrm{p}>0,05)$; no entanto, o grupo de experimento mostrou queda estatisticamente significativa dos níveis de ansiedade no período pós-operatório ( $\mathrm{p}<0,05)$. Conclusão: os níveis de estado de ansiedade das crianças que receberam preparo pré-operatório planejado são mais baixos em comparação com as crianças que não receberam esse treinamento. Reduzir os níveis de ansiedade de crianças doentes é possível quando se oferece informações visuais e palpáveis adequadas à idade e à fase de desenvolvimento da criança no período pré-operatório.

Palavras-chave: criança, pediatria, hérnia/cirurgia, ansiedade, assistência perioperatória.

\section{References}

1. Debes C, Aissou M, Beaussier M. [Preparing patients for surgery to improve functional recovery and reduce postoperative morbidity]. Ann Fr Anesth Reanim. 2014;33:33-40.

2. Guo P. Preoperative education interventions to reduce anxiety and improve recovery among cardiac surgery patients: a review of randomised controlled trials. J Clin Nurs. 2014;doi: 10.1111/jocn.12618. [Epub ahead of print]

3. Williams C. A background report on nurse staffing in children's and young people's health care: A review and analysis of the evidence. Commissioned by the Royal College of Nursing. Royal College of Nursing; 2013. Available at: https://www.rcn.org.uk/_data/assets/pdf_file/0007/527272/004369.pdf.

4. Wilson DG. Clinical guidelines: march 2014 to february 2015. Cardif and Vale University Health Board; 2014. Available at: http://www.cardiffpicu. com/pdf/CardiacClinical Guidelines2014.pdf.

5. Wong DL, Hockenberry-Eaton M. Health promotion of the adolescent and family. In: Hockenberry-Eaton M, editor. Wong's essentials of pediatric nursing. St Louis: Mosby Company; 2005. p.520-39.

6. Omaya I, Banihani MD, Michael C, Ost MD. Preparing the child for minimally invasive surgery and what parents and children truly remember. Pediatric Endourol Tech. 2013;30:323-31.

7. He HG, Zhu L, Li HC,Wang W, Vehvilainen-Julkunen K, Chan SW. A randomized controlled trial of the effectiveness of a therapeutic play intervention on outcomes of children undergoing inpatient elective surgery: study protocol. J Adv Nurs 2014;70:431-42.

8. Spielberger CD. Assesment of state and trait anxiety: conceptual and methodological issues. South Psychol. 1985;2:6-16.

9. Ozusta S. Adaptation, validity and reliability of State-Trait Anxiety Inventory for children. Türk Psikoloji Derg. 1995;10:32-44.

10. Sarı Ş, Tunç EŞ, Bilgin Z. Çocuklarda dental kaygının farklı test yöntemleri ile değerlendirilmesi: Karşılaştırılmalı bir çalışma. A Ü Diş Hek Fak Derg 2002;29:127-35.

11. Baygin O, Tuzuner T, Isık B, Arslan I, Tanriver M. Evaluation of the correlation between preoperative anxiety and pain level in children having primary tooth extractions. J Istanbul University Faculty Dentistry 2012;46:32-42.

12. Turan NK, Acaroglu R. The relationship between anxiety levels of adolescents who undergo surgical interventions and their parents and analysis of anxiety causes. Turkiye Klinikleri J Med Sci. 2012;32:308-15.

13. Ng SKS, Chau AW, Leung WK. The effect of preoperative information in relieving anxiety in oral surgery patients. Community Dent Oral Epidemiol 2004;32:227-35.

14. Kain ZN. Preoperative preparation in chidren: a cross-sectional study. J Clin Anesth. 1996;8:508-14.

15. Mooney KM. Preoperative management of the pediatric patient. J Plast Surg Nurs. 1997;17:69-75.

16. Caumo W, Broenstrub JC, Fialho L, Petry SMG, Bandeira D, Lougercio A, et al. Risk factors for postoperative anxiety in children. Acta Anaesthesiol Scand. 2000;44:782-89.

17. Watson AT, Visram A. Children's preoperative anxiety and postoperative behaviour. Pediatr Anesthesia. 2003;13:188-204.

18. William Li HC, Lam HYA. Paediatric day surgery: impact on Hong Kong Chinese children and their parents. J Clin Nurs. 2003;12:882-7.

19. Ucak H, Kivrak N. The painting booklet designed for children who are scheduled for adenoidectomy and/or tonsillectomy prepared for the patients and their parents. KBB-Forum 2011;10:31-4. Available at: URL: http://www. kbb-forum.net/journal/summary_en.php3?id=264. 